\title{
Learning Spanish as a foreign language through Music
}

\section{José Pérez-Carmona}

Universidad de Granada

mail: joseluisperezcarmonaAgmail.com

ORCID: https://orcid.org/0000-0002-0992-3309

\section{M. ${ }^{a}$-Teresa Díaz-Mohedo}

Universidad de Granada

mail: mtdiazm@ugr.es

ORCID: https://orcid.org/0000-0003-1719-6356

\author{
Alejandro Vicente-Bújez \\ Universidad de Granada \\ mail: alevicentedugr.es \\ ORCID: https://orcid.org/0000-0002-0822-1081 \\ José-Luis Ortega-Martín \\ Universidad de Granada \\ mail: ortegamaugr.es \\ ORCID: https://orcid.org/0000-0003-4875-0188
}

\begin{abstract}
Music has multiple characteristics that make it an ideal tool for teaching and learning languages. Although some research has been done on this subject, there are still many areas to explore. This quantitative research presents survey data from 178 students of Spanish as a Foreign Language to better understand how adult learners use music and other media in their practice of Spanish. Non-parametric statistical tests were carried out. Data showed participants used music more frequently than other media as a means to practice Spanish outside of the classroom, despite having difficulties understanding the lyrics. Also, musical training was found to be an indicator of a higher level of lyrical comprehension. It was concluded that the growing popularity of Spanish language music, changes in music consumption, and the democratization of listening platforms -along with the ability that songs have to generate well-being and to create links, as well as to represent the target culture- were decisive factors in the use of songs in the learning of Spanish as a foreign language.
\end{abstract}

Keywords: songs, music, Spanish as a foreign language, adults, media.

\section{El aprendizaje del español como lengua extranjera mediante la música}

\section{Resumen}

La música cuenta con unas características que la convierten en una herramienta idónea en la enseñanza-aprendizaje de idiomas. Si bien el mundo académico ha investigado al respecto, existen aún cuestiones sobre las que prácticamente no se ha indagado. En esta investigación cuantitativa, 178 estudiantes de español como lengua extranjera participaron contestando un cuestionario que buscaba conocer la manera en que estudiantes adultos usaban la música y otros medios para su práctica del español. Se realizaron pruebas estadísticas no paramétricas. A pesar de que los participantes declararon encontrar dificultades a la hora de entender las canciones, afirmaron que la música era el medio que más utilizaban para el aprendizaje de español. Además, se identificó el entrenamiento musical como indicador de un mayor entendimiento de las letras de canciones. Se concluyó que la popularidad creciente de la música en español, los cambios en el consumo musical y la democratización de las plataformas de escucha -junto con la capacidad de las canciones para generar bienestar, crear vínculos e impulsar la cultura meta- eran factores decisivos en el uso de las mismas en el aprendizaje del español como lengua extranjera (ELE).

Palabras clave: canciones, música, español como lengua extranjera, adultos, medios. 


\section{Introduction}

Spanish as a foreign language (SFL) teaching has both quantitatively and qualitatively increased over the last two decades. This has been driven by the creation of specific university study programmes, the intensification of the Cervantes Institute's worldwide activity and the consolidation of Spanish as an expanding language in the United States and Asian countries. In this regard, it is estimated that half of all students who study foreign language degrees or masters' programmes in the United States do so in Spanish (Instituto Cervantes, 2019). In Asian countries, such as China, learning Spanish as a foreign language has been seen to facilitate connections with Spanish-speaking countries (Lu et al., 2019).

There has also, simultaneously, been an increase in the popularity of Spanish language music. This is reflected in the US charts (Rivera-Rideau \& Torres-Leschnik, 2019). Technological advances have enabled the ubiquitous and practically unlimited creation of music platforms (Werner, 2020; Zhang et al., 2013) which facilitates user access to a vast variety of music. This fosters more eclectic interests and an openness to other languages. Furthermore, the digital era has brought with it a proliferation of language learning tools which facilitate the use of music as a means to learn SFL (Díaz-Bravo, 2015; Hornillos \& Roa, 2015).

In light of these facts, as well as the scientific evidence which highlights the benefits of using music in foreign language classrooms, it is necessary to find out to what extent music can be seen as a motivational tool which is useful for adult students when learning Spanish as a foreign language. It is also necessary to identify music products consumption habits (Greenberg \& Rentfrow, 2017) as well as the consumption habits for other forms of media (Fonseca-Mora \& García-Barroso, 2010). This research seeks to deepen this use of music by adult learners through a quantitative instrument. The resulting knowledge would enable reflection on the use of these products and their systematic didactic application in the classroom.

\subsection{Music and Foreign Language Learning}

In recent decades there has been a proliferation of scientific research which suggests a strong neural relationship between music and language (Jantzen et al., 2016; Jung et al., 2015), as well as the possibility of music and language both having a common origin (Brandt et al., 2012; Patel, 2014). Research into the psycho-social effects music has on human beings, the generation of affective processes (Trost et al., 2017), the creation of interpersonal bonds (Gill, 2012) and the contribution to social cohesion (Woolhouse et al., 2016) has also been conducted. Different approaches suggest music is a social communication device (Cross, 2010; Mithen, 2009) a means of generating well-being (Fuentes et al., 2017; Malloch \& Trevarthen, 2018), something which transcends the traditional vision of its artistic facet (Blacking, 1974; Brandt et al., 2012; Díaz-Mohedo \& Vicente-Bújez, 2018) and that can have positive effects on future teachers' expectations (Montilla-Coronado et al., 2018).

In the light of this research, generated by the scientific literature, studies into the benefits of using music when teaching a second language, such as, increasing short-term memory (Ludke et al., 2014) and textual retention (Kilgour et al., 2000); promoting involuntary training (Murphey, 1990); increasing semantic understanding (Fritz et al., 2019; Poulin-Charronnat et al., 2005); developing oral skills (Fernández-García \& Fonseca-Mora, 2019; Intartaglia et al., 2017); improving reading comprehension (Carmen Fonseca-Mora \& Gómez-Domínguez, 2015) and contributing to phonological improvement (Schön et al., 2008) have been carried out. It has been determined that the use of music reduces the anxiety generated by the process of learning a second language (Dolean, 2016), influences students' motivation (Espinar and Ortega-Martín, 2015) and willingness to communicate (Cores-Bilbao et al., 2019), and acts as a necessary input due to its emotional charge (Tim Murphey \& Alber, 1985). Music is also a testimony of culture from a holistic perspective (Brooks et al., 2020). Furthermore, research has identified a prominent influence which music training has on students of foreign languages (Fernández-Costales and González-Riaño, 2018, Flaugnacco et al., 2015; Posedel et al., 2012; Swaminathan et al., 2018).

There are however still very few studies which focus specifically on adult learners (Engh, 2013; Passiatore et al., 2019) and their approach to foreign language study. For Ardasheva et al. (2017), adult foreign language learning occurs in more diverse contexts than for children. Adults also tend to self-regulate their learning significantly more than children. In this sense, Murphey (2010) has stated that for adult learners, songs are one of the most powerful reasons to start and to continue learning a foreign language.

\section{Research questions}

Despite the numerous studies that have been performed on the use of music in SFL classrooms, very little research has been carried out on the independent use of music or other media forms by students. This research seeks to answer the following questions regarding the use of music by a group of adult foreign SFL students during a three-month stay in Spain.

1. How do participants evaluate their own language skills in relation to different acts of communication? Do differences exist based musical abilities, class enrollment or linguistic level?

2. Which media forms do participants most frequently use to support learning Spanish as a foreign language? Do differences exist according to musical knowledge, the classes they took or the linguistic level?

3. In which languages do they usually use these forms of media?

\section{Method}

\subsection{Participants}

A non-probabilistic sample of 178 foreign students ( $n$ female=147; $n$ male $=31$ ) enrolled at a Spanish language learning center associated with a public university in Andalusia was used. Participants were the second month of a 3-month course. The age of the participants was between 18 and 36 years $(M=20.81$; SD: 2.23$) .84 .8 \%$ of the participants came from the United States, $10.7 \%$ from China and the remaining $4.5 \%$ from Australia, Taiwan, Sweden, Japan and Canada. The mother tongue percentage distribution of participants was $77.5 \%$ English, 9.6\% bilingual (English and Spanish), $11.5 \%$ Chinese, $1.1 \%$ Japanese and $0.6 \%$ Swedish. $96.1 \%$ of participants were undertaking undergraduate studies at their reference universities. $66.3 \%$ were self-defined as musical performers. Following the criteria of the Common European Framework of Reference for Languages (Council of Europe, 2002) and the Instituto Cervantes, 30.3\% were at level B1.2, 25.8\% were at level B2.1 and $43.8 \%$ were at level B2.2.

\subsection{Questionnaire}

An adaptation of Ramírez's questionnaire (1992) was used as means data collection. It consisted of two sections. In the first section socio-demographic data was collected. The second section was comprised of 27 items of different types of response.

These items were grouped into 3 sections: 
- Self-assessment of communication skills. Likert 1-5.

- Methods used for practising SFL. Likert 1-5.

- Communicative habits and preferences. Nominal measurement variable.

Musical knowledge was measured according to the following criteria: a self-evaluation of instrumental mastery (scale of 0-10) and the years of musical studies taken (Shook et al., 2013). Those who took 4 or more years of music lessons and self-rated themselves with 5 or more mastering their instrument were identified as musicians.

In order to ensure the questionnaire quality, a group of experts from different branches of social sciences revised and then approved the adaptation after changes were made. To verify its statistical reliability, Cronbach's alpha was used for items which were measured on the ordinal Likert scale 1-5 but not for the items of nominal measurement. This resulted in coefficients between 0.813 and 0.944 .

In order to carry out the statistical analysis, Kolmogorov-Smirnov normality tests were performed, which obtained significant results in all items $(p<0.05)$. This indicates that the distribution was not normal. Non-parametric tests were therefore used. Frequencies, percentages, ranges and sums of ranges were used for data description. Frequencies were analysed using the Chi-square statistic. In addition, a Mann-Whitney $U$ test in function analysis of the musical knowledge variable was carried out. Kruskal-Wallis $\mathrm{H}$ test was performed for the language level variable since there were three different groups (B1.2, B2.1 and B2.2).

\section{Results}

\subsection{Communicative competence: Self-assessment of skills}

In this section participants were asked to describe and evaluate their aptitudes regarding different communicative activities using a 5-level Likert scale (1=extremely well, $2=$ very well, $3=$ well, $4=a$ little, $5=$ nothing). The activity which participants found easiest on the whole (see table 1) was "understanding a conversation in Spanish" $(\mathrm{m}=2.33)$. Conversely "understanding a song in Spanish" was the activity which participants found most difficult $(\mathrm{m}=3.17)$.

Table 1. Self-evaluation of communication skills in Spanish

\begin{tabular}{|l|c|c|}
\hline Item & M & SD \\
\hline understand a conversation & 2.33 & 0.930 \\
\hline participate in a conversation & 2.71 & 0.898 \\
\hline understand a magazine/newspaper & 2.50 & 0.878 \\
\hline write an e-mail & 2.48 & 0.891 \\
\hline understand song lyrics & 3.17 & 0.973 \\
\hline understand movies & 3.02 & 0.977 \\
\hline understando TV shows & 2.98 & 1.005 \\
\hline understando Youtube videos & 2.94 & 9.75 \\
\hline communicate by videocall & 2.91 & 1.004 \\
\hline understand social media & 2.47 & 0.975 \\
\hline
\end{tabular}

1=extremely well, $2=$ very well, $3=$ well, $4=$ a little, 5=nothing

\subsection{Means used for practising Spanish as a foreign language}

In the next section of the questionnaire, participants were asked to assess the frequency with which they used different media forms for practising Spanish as a foreign language (1=very much, $2=$ often, $3=$ sometimes, $4=$ rarely, $5=$ never) (see table 2 ). For the participants music was the most used medium $(\mathrm{m}=2.22)$, followed by TV series $(\mathrm{m}=2.45)$ and films $(\mathrm{m}=2.48)$. At the other end of the scale, YouTube was found to be the least used medium for learning and practicing Spanish $(\mathrm{m}=3.30)$, after reading books $(\mathrm{m}=3.16)$ and reading magazines or newspapers $(\mathrm{m}=3.14)$.

Table 2. Means used for practising Spanish as a foreign language

\begin{tabular}{|l|c|c|}
\hline Item & M & DS \\
\hline Books, cómics & 3.16 & 1.136 \\
\hline Music & 2.22 & 1.033 \\
\hline Tv News & 2.85 & 1.162 \\
\hline Movies & 2.48 & 1.048 \\
\hline TV Shows & 2.45 & 1.095 \\
\hline Social Media & 2.94 & 1.095 \\
\hline Youtube & 3.30 & 1.243 \\
\hline Newspaper, magazines & 3.14 & 1.144 \\
\hline Podcast & 2.97 & 1.105 \\
\hline
\end{tabular}

$1=$ very much, $2=$ often, $3=$ sometimes, $4=$ rarely, $5=$ never

\subsection{Analysis of the questionnaire according to the linguistic level}

Analysis was carried out according to linguistic level, both in the self-assessment of communication skills section and in the means used for practicing Spanish as a foreign language section. Data (see table 3) showed very significant differences in all the items of the self-evaluation, with higher level participants evaluating themselves more positively $(p<.01)$. No significant differences were found in the section referring to the means used for SFL practice.

Table 3. Self-evaluation of communication skills in Spanish based on linguistic level (H Krusal-Wallis test).

\begin{tabular}{|l|c|c|c|c|}
\hline \multirow{2}{*}{\begin{tabular}{l} 
Item can (...) in Spanish \\
\multirow{4}{*}{$\begin{array}{l}\text { understand } \\
\text { a conversation }\end{array}$}
\end{tabular}} & $\begin{array}{c}\text { Linguistic } \\
\text { level }\end{array}$ & Range & $\begin{array}{c}\text { H Kruskal- } \\
\text { Wallis }\end{array}$ & $p$-value \\
\cline { 2 - 5 } & B1.2 & 120.50 & 45.195 & $.000^{* * *}$ \\
\cline { 2 - 5 } & B2.1 & 97.78 & & \\
\hline \multirow{2}{*}{$\begin{array}{l}\text { participate } \\
\text { in a conversation }\end{array}$} & B1.2 & 63.15 & & \\
\cline { 2 - 5 } & B2.1 & 97.74 & & $.000^{* * * *}$ \\
\cline { 2 - 5 } & B2.2 & 65.99 & & \\
\hline
\end{tabular}




\begin{tabular}{|c|c|c|c|c|}
\hline $\begin{array}{l}\text { Item } \\
\text { I can (...) in Spanish }\end{array}$ & $\begin{array}{l}\text { Linguistic } \\
\text { level }\end{array}$ & Range & $\begin{array}{l}\text { H Kruskal- } \\
\text { Wallis }\end{array}$ & $p$-value \\
\hline \multirow{3}{*}{$\begin{array}{l}\text { understand } \\
\text { a magazine/ } \\
\text { newspaper }\end{array}$} & B1.2 & 121.44 & 41.501 & $.000 * * *$ \\
\hline & B2.1 & 91.87 & & \\
\hline & B2.2 & 65.99 & & \\
\hline \multirow{3}{*}{ write an e-mail } & B1.2 & 129.25 & 54.803 & $.000 * * *$ \\
\hline & B2.1 & 82.74 & & \\
\hline & B2.2 & 66.03 & & \\
\hline \multirow{3}{*}{$\begin{array}{l}\text { understand } \\
\text { song lyrics }\end{array}$} & B1.2 & 102.62 & 11.823 & $.003^{* *}$ \\
\hline & B2.1 & 98.11 & & \\
\hline & B2.2 & 75.34 & & \\
\hline \multirow{3}{*}{$\begin{array}{l}\text { understand } \\
\text { movies }\end{array}$} & B1.2 & 114.53 & 27.444 & $.000^{* * *}$ \\
\hline & B2.1 & 94.16 & & \\
\hline & B2.2 & 69.42 & & \\
\hline \multirow{3}{*}{$\begin{array}{l}\text { understand } \\
\text { Tv Shows }\end{array}$} & B1.2 & 113,45 & 23.066 & $.000 * * *$ \\
\hline & B2.1 & 91.60 & & \\
\hline & B2.2 & 71.68 & & \\
\hline \multirow{3}{*}{$\begin{array}{l}\text { understand } \\
\text { YouTube videos }\end{array}$} & B1.2 & 110.94 & 20.291 & $.000 * * *$ \\
\hline & B2.1 & 93.68 & & \\
\hline & B2.2 & 72.19 & & \\
\hline \multirow{3}{*}{$\begin{array}{l}\text { communicate } \\
\text { by videocall }\end{array}$} & B1.2 & 116.19 & 30.681 & $.000^{* * *}$ \\
\hline & B2.1 & 94.33 & & \\
\hline & B2.2 & 68.17 & & \\
\hline \multirow{3}{*}{ use social media } & B1.2 & 118.44 & 29.554 & $.000 * * *$ \\
\hline & B2.1 & 86.42 & & \\
\hline & B2.2 & 71.28 & & \\
\hline
\end{tabular}

\subsection{Communication habits and preferences}

In this section the aim was to find out in which languages participants usually carried out or preferred to carry out a series of communicative activities. In this case, in an attempt not to establish an order of preference, the variables were of a nominal nature. The aim was to find out what presence different languages had in everyday activities, (leisure, study, etc.) and to investigate whether these customs or trends varied in the different mother tongue groups.

In order to determine in what percentage activities were carried out a descriptive cross table analysis was performed. It should be noted that both the group of Japanese and Swedish speakers were very small in number, so these results were not taken into account in this case.

Among the group of native English speakers (see table 4), more than half $(57.2 \%)$ stated that they listened to music in both English and in Spanish, compared with 38.5\% who preferred to only listen in English and 4.3\% who preferred to only listen in Spanish. It was in this the activity that the combination of the two languages generated the highest percentage, at the opposite end of the scale was "conversation with friends", an activity that only $14.7 \%$ claimed to carry out in both Spanish and English. Also of note was listening to podcasts in English and Spanish, which only occurred among 20.3\% of English speakers and the use of social networks, which accounted for $19.5 \%$. Although the percentage of participants who sang in Spanish and English was low (33.6\%) within this group, $81.8 \%$ of those were musicians.

Table 4. Language in which communication activities were carried out: English speakers

\begin{tabular}{|l|c|c|c|}
\hline \multirow{2}{*}{ Item } & \multicolumn{3}{|c|}{ Language } \\
\cline { 2 - 4 } & $S$ & $E$ & $S+E$ \\
\hline Listening to songs & $4.3 \%$ & $38.5 \%$ & $57.5 \%$ \\
\hline Singing & $2.9 \%$ & $63.8 \%$ & $33.6 \%$ \\
\hline Talking to friends & & $85.5 \%$ & $14.5 \%$ \\
\hline Writing e-mail & $2.2 \%$ & $65.9 \%$ & $31.8 \%$ \\
\hline Using social media & $2.9 \%$ & $77.5 \%$ & $19.5 \%$ \\
\hline Listening to podcast & $1.4 \%$ & $78.2 \%$ & $20.3 \%$ \\
\hline Watching movies & $4.3 \%$ & $52.2 \%$ & $43.4 \%$ \\
\hline Watching TV shows & $3.6 \%$ & $46.4 \%$ & $50 \%$ \\
\hline Texting/Whatsapp & $3.6 \%$ & $43.4 \%$ & $52.8 \%$ \\
\hline
\end{tabular}

E=English, S=Spanish

Analysis was carried out according to musical experience, both in the self-assessment of communication skills section and in the means used for practising Spanish as a foreign language section. The data showed significant differences only occurred in the "I can understand songs in Spanish" item of the self-assessment, where participants with musical experience were more able to understand songs in Spanish $(p=.005)$. No significant differences were found in the section referring to the means used for SFL practice.

No significant differences were found between students enrolled in subjects with musical content and those who did not take any subjects either in the self-evaluation scale or in the scale referring to the means used.

Among the native Chinese speakers (see table 5), 35\% of participants said they listened to music in both Spanish and English, compared to $20 \%$ who did so only in Chinese and $15 \%$ who did so in Spanish, English and Chinese. The highest percentages for the rest of the activities, which were more widespread as there were more options, since in addition to the mother tongue (Chinese) and the target language (Spanish) they also practiced English, were all found to be in the mother tongue category. $71.4 \%$ of those who sang only in their mother tongue were among those self-identified as not musicians. 
Table 5. Language in which communication activities were carried out: English speakers

\begin{tabular}{|c|c|c|c|c|c|c|c|}
\hline \multirow{2}{*}{ Item } & \multicolumn{7}{|c|}{ Language } \\
\hline & $C$ & $S$ & E & $C+S$ & $C+E$ & $S+E$ & $C+S+E$ \\
\hline Listening to songs & $20 \%$ & & $5 \%$ & $10 \%$ & $15 \%$ & $35 \%$ & $15 \%$ \\
\hline Singing & $35 \%$ & & $5 \%$ & $5 \%$ & & $25 \%$ & $30 \%$ \\
\hline Talking to friends & $50 \%$ & & & $5 \%$ & $10 \%$ & & $35 \%$ \\
\hline Writing e-mail & $40 \%$ & & $10 \%$ & $25 \%$ & & $15 \%$ & $10 \%$ \\
\hline Using social media & $35 \%$ & & $10 \%$ & $10 \%$ & $5 \%$ & $20 \%$ & $20 \%$ \\
\hline Listening to podcast & $50 \%$ & $5 \%$ & & $5 \%$ & $5 \%$ & $20 \%$ & $15 \%$ \\
\hline Watching movies & $20 \%$ & $5 \%$ & $5 \%$ & $10 \%$ & $10 \%$ & $30 \%$ & $20 \%$ \\
\hline Watching TV shows & $35 \%$ & $5 \%$ & $5 \%$ & $5 \%$ & $10 \%$ & $25 \%$ & $15 \%$ \\
\hline Texting/Whatsapp & $35 \%$ & & $5 \%$ & $10 \%$ & $5 \%$ & $15 \%$ & $30 \%$ \\
\hline
\end{tabular}

$\mathrm{C}=$ Chinese, $\mathrm{S}=$ Spanish, $\mathrm{E}=$ English

Finally, for the participants who declared themselves to be bilingual (see table 6) in English and Spanish, the vast majority $(94.1 \%)$ claimed to listen to music in both languages. This was also the activity which they did most often in both languages. On examination of other activities such as listening to podcasts $(41.2 \%)$, watching films $(47.1 \%)$, or watching series $(52.1 \%)$, it can be noted that these percentages are lower and the favoured language was English. After listening to music in both languages, came the use of instant messaging (70.6\%) and singing (64.7\%). There is a difference between the languages in which music is listened to and in which it is sung, with a considerably lower number of participants declaring that they sing in Spanish as well as in English. However, within these it was identified that among the musicians, 87.5\% sang in English and Spanish, while among the non-musicians, only $44.4 \%$ sang in both languages.

Table 6. Language in which communication activities were carried out: Bilingual speakers

\begin{tabular}{|l|c|c|c|}
\hline \multirow{2}{*}{ Item } & \multicolumn{3}{|c|}{ Language } \\
\cline { 2 - 4 } & $S$ & $E$ & $S+E$ \\
\hline Listening to songs & & $5.9 \%$ & $94.1 \%$ \\
\hline Singing & $5.9 \%$ & $29.4 \%$ & $64.7 \%$ \\
\hline Talking to friends & $11.8 \%$ & $52.9 \%$ & $35.5 \%$ \\
\hline Writing e-mail & & $52.9 \%$ & $47.1 \%$ \\
\hline Using social media & & $52.9 \%$ & $47.1 \%$ \\
\hline Listening to podcast & $5.9 \%$ & $52.9 \%$ & $41.2 \%$ \\
\hline Watching movies & $5.9 \%$ & $47.1 \%$ & $47.1 \%$ \\
\hline Watching TV shows & $5.9 \%$ & $41.2 \%$ & $52.9 \%$ \\
\hline Texting/Whatsapp & & $29.4 \%$ & $70.6 \%$ \\
\hline
\end{tabular}

E=English, S=Spanish

\section{Discussion}

\subsection{Communicative competence: Self-assessment of skills}

The results obtained from the self-assessment of Spanish communication skills showed that listening to songs proved to be the most difficult activity for the participants. Songs have certain peculiarities which can make them difficult to understand on initial contact. Lack of visual support, the occasional inconsistency between rhythmic and musical accents and the possible negative influence which harmonic processes can have on phoneme processing and semantic understanding are a few of these peculiarities (Poulin-Charronnat et al., 2005). In contrast, with written texts the reader can take more time to understand them and/or create them and videos and films have images which provide context to broaden understanding of content.

For Murphey (2019) the simplicity of songs and their repetition is something to be taken into account when learning a second language. For Schön et al. (2008) during the learning of a second language, the structural and motivational properties of music in songs facilitate the segmentation of new words. According to these authors, repetition facilitates cognitive processing: “(...) redundant information in general is easier to process, not only across the linguistic and musical domains, but more generally throughout cognitive domains" (2008, p. 982) The clarity which a song may lack on an initial listening is compensated for by its emotional charge (Malloch \& Trevarthen, 2018), as well as by the synchronic attraction it generates (Jung et al., 2015), its ability to resonate in our head (Tim Murphey, 1990) and the mnemonic quality of the melody, which facilitates long-term storage of the vocabulary (Gordon et al., 2010).

The significant differences based on the musical knowledge coincide with previous research (Flaugnacco et al., 2015; Posedel et al., 2012; Swaminathan et al., 2018). Musical knowledge plays a significant role in the self-perception of participants' ability to understand songs in Spanish. Practising music thus stands out as an effective tool for understanding songs in Spanish. Future research will discover whether the continued use of music materials which systematically include musical performance would benefit the acquisition of SFL. While language level did influence 
the self-assessment of communicative skills as expected, it did not influence the evaluation of the different media for the practice of Spanish as a foreign language.

\subsection{Means for Spanish practice}

In accordance with Murphey's research (2010), music stood out as the most used means to practice SFL independently for the participants. This is in contrast to the participants themselves stating that they found it more difficult to understand songs than any of the other option variables. However, there are certain characteristics which may influence why it was the most chosen option by the participants when learning and practising Spanish.

Due to technological advances and streaming platforms such as Spotify, Google Music, etc., users have virtually unlimited and ubiquitous access to a wide variety of music (Zhang et al., 2013). Moreover, unlike other audio-visual products, it is possible to simultaneously do other activities while listening to it (Fuentes et al., 2017) and it is the user who decides how much attention they are going to pay. When not paying attention to the linguistic content, music continues to influence our emotions due to a phenomenon called entrainment: "the powerful, external rhythm of the music interacts with an internal body rhythm of the listener such as heart rate, so that the listener's rhythm adjusts to it and eventually 'locks in' to a common periodicity" (Juslin et al., 201, p.621), generating a feeling of well-being due to a release of dopamine.

Music acts on two different levels: a conscious level, where the listener listens and is totally focused on it, both on extra-musical elements (the text, the singer's attitude, etc.) as well as on musical aspects (the instrumentation, the musical texture, the experience of the listener and the sound quality, etc.); and an unconscious level, in which thought can be distanced from musical fact while its rhythmic, melodic, agogic and dynamic aspects influence the individual on an emotional and physical level. This dual quality of music is not present in the other media forms which are proposed for learning foreign languages. This gives music with a privileged position on the list of students' preferences.

Music is, as well as being an artistic product, a means of communication which has great influence on human beings' socialisation (Carlson et al., 2019; Cross, 2010). It is not only what is listened to and how, but where, when and with whom. Despite the fact that a large part of the music listened to today accompanies us in moments of isolation, it still affects the way in which our social relations are shaped, as a type of negotiation between our own and other people's interests (Gran et al., 2020). It is evident that media forms in which entertainment and learning are combined and more popular among SFL students, especially if they are real (Galindo Merino, 2006), authentic materials (Fandiño López et al., 2008).

In conclusion, the motivation that authentic material of an artistic nature can produce in students, together with the emotion music brings out in the listener, as well as its capacity to establish social bonds, makes it an attractive tool for SFL practice, as was confirmed by the results of our questionnaire.

\subsection{Communication habits and preferences}

For participants, listening to music was the most practised act of communication in Spanish (as well as other languages) ahead of others such as watching films or series (regardless of the individual's mother tongue). It is worth noting that $94.1 \%$ of bilingual speakers (all from the USA) stated that they listened to music in English and Spanish while all other activities were mostly done solely in English. Music possesses a cultural identity that bilingual speakers embrace as their own and, although the idea of the Latino can provoke thoughts of only one culture or distort the idea of non-Hispanic speakers (Rivera-Rideau \& Torres-Leschnik, 2019) it allows, in turn, the vindication of a community which has become the majority minority in the United States. In this sense, Marshall \& Naumann (2018) state that musical preferences offer a closer view of personality than film, clothes, food, book, or television programme preferences do, and that these choices are appreciated as ways of communicating racial or cultural identities.

In point 5.1, the difficulty which participants experienced in understanding music was discussed. This was in contrast to the fact that this is the activity which is most performed in Spanish along with the native language (as well as in English in the case of Chinese speakers). According to Greenberg \& Rentfrow (2017) music accompanies people between $11 \%$ and $44 \%$ of their conscious time and is chosen by adolescents in several countries as their favourite activity (Fuentes et al., 2017). The expansion of the Hispanic culture throughout the world, and more specifically throughout the United States, is generating a change in the music worldwide scene, where there is now more room for musical phenomena which deviate from standard classic American bestsellers. The consolidation of the Latin Grammys (Martínez, 2006), together with the increasing presence of artists singing in Spanish on the Billboard Hot 100, have contributed to Spanish-language music becoming more present on the playlists of young non-Spanish speakers. This increased appreciation of the target culture has been identified by Gardner (1985) as an influential factor in the success of learning a second language, whose mastery requires identification with the culture that uses it.

For Cross, music has a floating intention, allowing "participants at a musical event to endow it with their individual and private meanings" (2010 p.15). The important emotional charge of music balances out the possible initial difficulty of understanding the lyrics of the songs and produces a greater acceptance by the audience, who will accept iconic references through emotion (Mithen, 2006). In other words, music does not have to provide concrete referential meanings but it has a deep impact on our emotions and makes us move through the rhythmic drag or entrainment, decisively affecting our idea of belonging to a group (Carlson et al., 2019; Gill, 2012; Trost et al., 2017).

The data shows participants did not sing in Spanish as much as might be expected. This could be due to several reasons. Firstly, the difficulty understanding songs which was expressed by the participants would have a negative influence on their desire to sing them or their habit of singing them. Being able to sing and memorise song lyrics requires multiple listening exercises and some research. The attention paid during listening to music, which can be done simultaneously with others, can vary according to the individual, which would influence their ability to pay attention to the linguistic part of the song. Also, being in a different context than the one they were used to could have influenced the reduction of certain habits that require self-confidence, such as singing (Lidman-Magnusson, 2013). In addition, the participants identifying themselves as musicians or non-musicians has to be taken into account. "Making music" can influence an individual's interest in and ease of performing pieces which are not part of one's own culture, such as the Hispanic culture (Dittinger et al., 2019; Fernández-García \& Fonseca-Mora, 2019; Posedel et al., 2012). A greater musical interpretation ability leads to a higher probability not only to listen to, but also to assimilate to the text associated with the music within the song. For Tim Murphey, from Kanda University, voluntary singing makes the student start to consider the song as their own and to incorporate it into their 
inner thinking or inner talk: "I would say that music and lyrics by themselves can teach up to a point, but with the voluntary singing of it with students create ownership of the song, its vocabulary, and meanings" (personal communication, May 20 $0^{\text {th }}, 2020$ ). This internalisation of sounds, words and sentence patterns will lead the student to use them in other non-musical situations (Passiatore et al., 2019). Finally, we believe that there is a lack of information among students about how singing can benefit learning and the acquisition of a second or foreign language (Engh, 2013). This must be corrected in order for students to take control of their learning, which, in the case of second languages, takes place both inside and outside an educational environment.

\section{Conclusions and limitations}

This study allowed us to ascertain the aptitudes and musical habits related to learning Spanish as a Foreign Language (SFL) of students a Spanish language learning center associated with a public university in Andalusia. Listening to songs, despite requiring a greater effort in understanding than reading, the use of social networks, watching films or having a conversation, among others, was found to be the activity which was carried out most often in Spanish, as well as being the most widely used medium for practising and learning SFL by the participants (Murphey, 2010). It was found that having musical knowledge was directly related to the participants' ability to understand songs.

The characteristics of music which makes it an ideal tool for SFL students were discussed: its capacity to endure in memory due to melody and rhythm, as well as natural repetition; its emotional charge and its synchronic possibilities, which enable the fostering of feelings of belonging to a group without the literalness of verbal language; and the current state of Spanish language music, the international dimension of which is on the rise, which facilitates intrinsic motivation in a student with access to a wide variety of music. Listening to music has also become a more frequent activity, due to the use of new devices and the democratisation of the internet (Fuentes et al., 2017).

Despite the encouraging results, a study with a larger number of participants could prove more consistent and reliable. Also, it should be noted that the participants in this study were in a context of cultural immersion different from that which students may experience in their home countries, which may have influenced their interest in the artistic-cultural products (music among them) of the target culture (Stroud, 2010). Conducting this study in a context of non-language cultural immersion could shed light on students' interest in music as a tool for SFL learning.

In addition, SFL teachers' visions should be taken into account regarding the use of music, in order to identify the aspects which should be addressed in order to use this technique more systematically in the classroom (Alisaari \& Heikkola, 2017).

\section{Bibliographical References}

Alisaari, J., \& Heikkola, L. M. (2017). Songs and poems in the language classroom: Teachers' beliefs and practices. Teaching and Teacher Education, 63, 231-242. https://doi.org/10.1016/j. tate.2016.12.021

Ardasheva, Y., Wang, Z., Adesope, O. O., \& Valentine, J. C. (2017). Exploring Effectiveness and Moderators of Language Learning Strategy Instruction on Second Language and Self-Regulated Learning Outcomes. In Review of Educational Research (Vol. 87, Issue 3, pp. 544-582). https://doi. org/10.3102/0034654316689135
Blacking, J. (1974). How musical is man? In Notes (Vol. 31, Issue 1). University of Washington Press. https://doi.org/10.2307/895922

Brandt, A., Gebrian, M., \& Slevc, L. R. (2012). Music and early language acquisition. Frontiers in Psychology, 3(SEP), 1-17. https:// doi.org/10.3389/fpsyg.2012.00327

Brooks, M., Wolfgang, J., Adams, J., Armstrong, N., \& Cassidy, R. (2020). Using Rap Music to Better Understand African American Experiences. Journal of Creativity in Mental Health, 1-17. https://doi.org/10.1080/15401383.2020.1732251

Carlson, E., Burger, B., \& Toiviainen, P. (2019). Empathy, entrainment, and perceived interaction in complex dyadic dance movement. Music Perception, 36(4), 390-405. https://doi. org/10.1525/MP.2019.36.4.390

Carmen Fonseca-Mora, M., \& Gómez-Domínguez, M. (2015). Instrumentos de investigación para el studio del efecto de la música en el desarrollo de las destrezas lectoras. Porta Linguarum, 24, 121-134. DOI: 10.30827/digibug.53804

Consejo de Europa. (2002). Marco Común Europeo De Referencia Para Las Lenguas. In Centro Virtual Cervantes.

Cores-Bilbao, E., Fernández-Corbacho, A., Machancoses, F. H., \& Fonseca-Mora, M. C. (2019). A Music-Mediated Language Learning Experience: Students' Awareness of Their Socio-Emotional Skills. Frontiers in Psychology, 10(October), 1-10. https://doi.org/10.3389/fpsyg.2019.02238

Cross, I. (2010). Cross, I. (2010). La música en la cultura y la evolución. Epistemus. Revista de Estudios En Música, Cognición y Cultura, 1(1), 9. https://doi.org/10.21932/epistemus.1.2700.0

Díaz-Bravo, R. (2015). Las canciones en la enseñanza- aprendizaje de ELE en la era digital. Porta Linguarum, 24, 203-214. https:// doi.org/10.30827/digibug.53871

Díaz-Mohedo, Ma T. \& Vicente-Bújez, A. (2018). Breaking boundaries in the neoliberal society: flamenco music as a crosscultural tool to teach Spanish as a foreign language. In: Djuraeva, M. and Tochon, F. V. [Eds.]. Language Policy or the Politics of Language: Re-imagining the Role of Language in a Neoliberal Society. Madison-Wisconsin: Deep University Press. pp. 255-281.

Dittinger, E., Scherer, J., Jäncke, L., Besson, M., \& Elmer, S. (2019). Testing the influence of musical expertise on novel word learning across the lifespan using a cross-sectional approach in children, young adults and older adults. Brain and Language, 198(August). https://doi.org/10.1016/j.bandl.2019.104678

Dolean, D. D. (2016). The effects of teaching songs during foreign language classes on students' foreign language anxiety. Language Teaching Research, 20(5), 638-653. https://doi. org/10.1177/1362168815606151

Engh, D. (2013). Why use music in English language learning? a survey of the literature. English Language Teaching, 6(2), 113127. https://doi.org/10.5539/elt.v6n2p113

Espinar Redondo, R., \& Ortega Martín, J. L. (2015). Motivation: The road to successful learning. PROFILE Issues in Teachers' Professional Development, 17(2), 125-136. http://dx.doi. org/10.15446/profile.v17n2.50563

Fandiño López, Z., Torras, A. V., Fandiño López, Z., \& Torras, A. V. (2008). Canciones en la clase de ELE. Jornadas de Formación Del Profesorado En La Enseñanza de ELE y La Literatura Española Contemporánea, Abril 2008, 177-186.

Fernández-García, A., \& Fonseca-Mora, M. C. (2019). EFL learners' speaking proficiency and its connection to emotional understanding, willingness to communicate and musical experience. Language Teaching Research, 43(2), 154-167. https:// doi.org/10.1177/1362168819891868

Fernández-Costales, A., \& González-Riaño, X. A. (2018). Satisfaction degree of English teachers of Preschool and Primary 
Education in the Principality of Asturias. Aula Abierta, 47(4), 463. https://doi.org/10.17811/rifie.47.4.2018.463-470

Flaugnacco, E., Lopez, L., Terribili, C., Montico, M., Zoia, S., \& Schön, D. (2015). Music training increases phonological awareness and reading skills in developmental dyslexia: A randomized control trial. PLOS ONE, 10(9), 1-17. https://doi. org/10.1371/journal.pone.0138715

Fonseca-Mora, C., \& García-Barroso, L. (2010). Aprender Español en USA: Los medios de comunicación como motivación social. Comunicar, 17(34), 145-153. https://doi.org/10.3916/C34-201003-14

Fritz, T. H., Schütte, F., Steixner, A., Contier, O., Obrig, H., \& Villringer, A. (2019). Musical meaning modulates word acquisition. Brain and Language, 190(February 2018), 10-15. https:// doi.org/10.1016/j.bandl.2018.12.001

Fuentes, C., Hagberg, J., \& Kjellberg, H. (2017). Digitalized music: Entangling consumption practices, in Digitalizing Consumption: How devices shape consumer culture. European Journal of Marketing, 53(3), 483-503. https://doi.org/10.1108/EJM-102017-0753

Galindo Merino (2006). La transferencia pragmática en el aprendizaje de ELE. La Competencia Pragmática y La Enseñanza Del Español Como Lengua Extranjera. Actas Del XVI Congreso Internacional de ASELE. Universidad de Oviedo: Oviedo.

Gardner, R. C. (1985). Social psychology and second language learning : the role of attitudes and motivation. E. Arnold. https://doi. org/10.1017/s0272263100007634

Gill, S. P. (2012). Rhythmic synchrony and mediated interaction: Towards a framework of rhythm in embodied interaction. AI and Society, 27(1), 111-127. https://doi.org/10.1007/s00146-0110362-2

Gordon, R. L., Schön, D., Magne, C., Astésano, C., \& Besson, M. (2010). Words and melody are intertwined in perception of sung words: EEG and behavioral evidence. PLOS ONE, 5(3). https://doi.org/10.1371/journal.pone.0009889

Gran, A.-B., Booth, P., \& Bucher, T. (2020). To be or not to be algorithm aware: a question of a new digital divide? Information, Communication $\mathcal{E}$ Society, 1-18. https://doi.org/10.1080/1369118X.2020.1736124

Greenberg, D. M., \& Rentfrow, P. J. (2017). Music and big data: a new frontier. Current Opinion in Behavioral Sciences, 18, 50-56. https://doi.org/10.1016/j.cobeha.2017.07.007

Hornillos, R. C., \& Roa, J. de D. V. (2015). La música, un instrumento en la enseñanza del español como lengua extranjera mediante la aplicación de las nuevas tecnologías. Porta Linguarum, 23, 139-151. https://doi.org/10.30827/digibug.53763

Instituto Cervantes. (2019). El español: una lengua viva. In Anuario. https://cvc.cervantes.es/lengua/espanol_lengua_viva/

Intartaglia, B., White-Schwoch, T., Kraus, N., \& Schön, D. (2017). Music training enhances the automatic neural processing of foreign speech sounds. Scientific Reports, 7(1), 1-7. https://doi. org/10.1038/s41598-017-12575-1

Trost, W., Labbé, C., \& Grandjean, D. (2017). Rhythmic entrainment as a musical affect induction mechanism. Neuropsychologia, 96(December 2016), 96-110. https://doi.org/10.1016/j. neuropsychologia.2017.01.004

Jantzen, M. G., Large, E. W., \& Magne, C. (2016). Editorial: Overlap of neural systems for processing language and music. In Frontiers in Psychology (Vol. 7, Issue JUN). https://doi. org/10.3389/fpsyg.2016.00876

Jung, H., Sontag, S., Park, Y. B. S., \& Loui, P. (2015). Rhythmic effects of syntax processing in music and language. Frontiers in Psychology, 6(NOV), 1-11. https://doi.org/10.3389/ fpsyg.2015.01762
Juslin, P., Liljeström, S., Västfjäll, D., \& Lundqvist, L.-O. (2010). How does music evoke emotions? Exploring the underlying mechanisms. In Handbook of Music and Emotion (pp. 605-642, Handbook of Music and Emotion (2nd ed)). https://doi. org/10.1093/acprof:oso/9780199230143.003.0022

Kilgour, A. R., Jakobson, L. S., \& Cuddy, L. L. (2000). Music training and rate of presentation as mediators of text and song recall. Memory and Cognition, 28(5), 700-710. https://doi. org/10.3758/BF03198404

Lu, X., Zheng, Y., \& Ren, W. (2019). Motivation for learning Spanish as a foreign language: The case of Chinese L1 speakers at university level. Circulo de Linguistica Aplicada a La Comunicacion, 79, 79-98. https://doi.org/10.5209/clac.65649

Ludke, K. M., Ferreira, F., \& Overy, K. (2014). Singing can facilitate foreign language learning. Memory and Cognition, 42(1), 41-52. https://doi.org/10.3758/s13421-013-0342-5

Malloch, S., \& Trevarthen, C. (2018). The human nature of music. Frontiers in Psychology, 9(OCT), 1-21. https://doi.org/10.3389/ fpsyg.2018.01680

Marshall, S. R., \& Naumann, L. P. (2018). What's your favorite music? Music preferences cue racial identity. Journal of Research in Personality, 76, 74-91. https://doi.org/10.1016/j. jrp.2018.07.008

Martínez, K. Z. (2006). American idols with Caribbean soul: Cubanidad and the Latin Grammys. Latino Studies, 4(4), 381-400. https://doi.org/10.1057/palgrave.lst.8600222

Mithen, S. (2006). The Singing Neanderthals: Overview. Cambridge Archaeological Journal. https://doi.org/10.1017/ s0959774306000060

Mithen, S. (2009). The music instinct: The evolutionary basis of musicality. Annals of the New York Academy of Sciences, 1169, 3-12. https://doi.org/10.1111/j.1749-6632.2009.04590.x

Montilla-Coronado, M.V., Maraver-López, Pablo, Romero Oliva, C. \& Martín Montilla, A. (2018). Análisis de las expectativas del profesorado novel sobre su futura labor docente. Aula Abierta, 47(2), 185-192. https://doi.org/10.17811/ rifie.47.2.2018.185-192

Murphey, T. (2010). Gracias a la vida-música que me ha dado tanto: songs as scaffolded-languaging for SLA. Linguagem $E$ Cognição, 241-255.

Murphey, Tim. (1990). The song stuck in my head phenomenon: A melodic din in the lad? System, 18(1), 53-64. https://doi.or$\mathrm{g} / 10.1016 / 0346-251 \times(90) 90028-4$

Murphey, Tim. (2019). English through Music: Singing TPR, Walking Labs , \& Music Matter. January.

Murphey, Tim, \& Alber, J. L. (1985). A Pop Song Register: The Motherese of Adolescents as Affective Foreigner Talk. In TESOL Quarterly (Vol. 19, Issue 4, p. 793). https://doi. org/10.2307/3586679

Passiatore, Y., Pirchio, S., Oliva, C., Panno, A., \& Carrus, G. (2019). Self-efficacy and anxiety in learning English as a Foreign language: Singing in class helps speaking performance. Journal of Educational, Cultural and Psychological Studies, 2019(20), 121138. https://doi.org/10.7358/ecps-2019-020-passi

Patel, A. D. (2014). The Evolutionary Biology of Musical Rhythm: Was Darwin Wrong? PLoS Biology, 12(3), 1-6. https://doi. org/10.1371/journal.pbio.1001821

Posedel, J., Emery, L., Souza, B., \& Fountain, C. (2012). Pitch perception, working memory, and second-language phonological production. Psychology of Music, 40(4), 508-517. https://doi. org/10.1177/0305735611415145

Poulin-Charronnat, B., Bigand, E., Madurell, F., \& Peereman, R. (2005). Musical structure modulates semantic priming in vo- 
cal music. Cognition, 94(3), B67-B78. https://doi.org/10.1016/j. cognition.2004.05.003

Ramírez, A. G. (1992). El español de los Estados Unidos : el lenguaje de los hispanos. Mapfre.

Rivera-Rideau, P., \& Torres-Leschnik, J. (2019). The colors and flavors of my Puerto Rico: Mapping “despacito"'s crossovers. Journal of Popular Music Studies, 31(1), 87-108. https:// doi.org/10.1525/jpms.2019.311009

Schön, D., Boyer, M., Moreno, S., Besson, M., Peretz, I., \& Kolinsky, R. (2008). Songs as an aid for language acquisition. Cognition, 106(2), 975-983. https://doi.org/10.1016/j.cognition.2007.03.005

Swaminathan, S., Schellenberg, E. G., \& Venkatesan, K. (2018). Explaining the association between music training and reading in adults. In Journal of Experimental Psychology: Lear- ning, Memory, and Cognition (Vol. 44, Issue 6, pp. 992-999). American Psychological Association. https://doi.org/10.1037/ $x \operatorname{lm} 0000493$

Werner, A. (2020). Organizing music, organizing gender: algorithmic culture and Spotify recommendations. Popular Communication, 18(1), 78-90. https://doi.org/10.1080/15405702.20 20.1715980

Woolhouse, M. H., Tidhar, D., \& Cross, I. (2016). Effects on Inter-Personal Memory of Dancing in Time with Others. Frontiers in Psychology, 7(February), 1-8. https://doi.org/10.3389/ fpsyg.2016.00167

Zhang, B., Kreitz, G., Isaksson, M., Ubillos, J., Urdaneta, G., Pouwelse, J. A., \& Epema, D. (2013). Understanding user behavior in Spotify. 2013 Proceedings IEEE INFOCOM. https:// doi.org/10.1109/infcom.2013.6566767 
